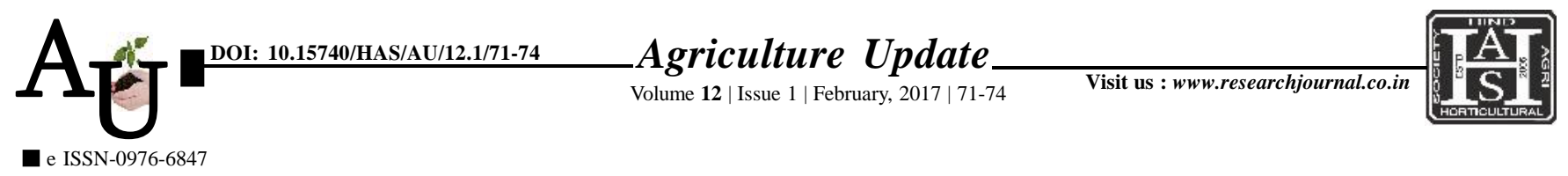

\title{
Rевевсни автіст: Attitude of beneficiary respondents towards Rastriya Krishi Vakash Yojana
}

\author{
SUNITA KUMARI AND F.L. SHARMA
}

Article Chronicle:

Received :

30.11.2016;

Revised :

21.12.2016;

Accepted :

30.12.2016
KEY WoRds:

Attitude, Beneficiary respondents, Tribal area, Non-tribal area, RKVY
Author for correspondence :

\section{SUNITA KUMARI}

Department of

Extension Education,

Rajasthan College of

Agriculture, Maharana

Pratap University of

Agricultural University,

UDAIPUR (RAJASTHAN)

INDIA

Email:sunitaladsar

@gmail.com

See end of the article for

authors' affiliations
SUMMARY : The present study was conducted in which two tribal (Jhadol and Sarada) and two nontribal (Bhinder and Mavli) Panchayat samities of Udaipur district of Rajasthan. Four beneficiary villages and two non-beneficiary villages from each selected Panchayat samiti were taken and 10 respondents were selected randomly from each selected village for the study. Data were collected through prestructured interview schedule. The findings revealed that 11.87 per cent respondents had least favourable towards RKVY. On the other hand, 68.75 per cent respondents belonged to moderately favourable group. However, 19.38 per cent respondents had highly favourable attitude towards RKVY. It indicated positive impact of the project under study.

How to cite this article : Kumari, Sunita and Sharma, F.L. (2017). Attitude of beneficiary respondents towards Rastriya Krishi Vakash Yojana. Agric. Update, 12(1): 71-74; DOI : 10.15740/HAS/AU/12.1/71-74. 